\title{
EU Operational Powers and Legal Protection: A Legal Theory Perspective on the Operational Powers of the European Border and Coast Guard
}

\author{
Bas Schotel ${ }^{\star}(1)$ \\ Faculty of Law and Paul Scholten Centre for Jurisprudence, University of Amsterdam, Amsterdam, Netherlands \\ *Corresponding author: b.schotel1@uva.nl
}

(Received 30 March 2020; accepted 24 August 2020)

\begin{abstract}
For the first time in its history, the EU is in the process of acquiring significant and genuine permanent operational powers. A new Regulation on the European Border and Coast Guard provides Frontex with a permanent corps of 10,000 border guards-3,000 of which will be EU agents-its own equipment, and its own competences to intervene along the EU borders and beyond. The operational powers will allow the EU to directly and physically intervene in tangible reality.

This Article argues that the conferral of operational powers on the EU poses a risk to individual legal protection. This is because once authorities have acquired operational powers of a certain extent and quality, they can afford to act against or without the law by simply overpowering or eluding the legal mechanisms that normally constrain the exercise of public power. So far, Members of the European Parliament and academics critical of Frontex and the new Regulation have overlooked this issue and concentrated exclusively on how to legally constrain the exercise of operational powers. This Article addresses this blind spot by examining whether and how public law should place legal constraints not only on the exercise but also on the build-up of operational powers.
\end{abstract}

Keywords: Frontex/European border and coast guard; operational powers; legal protection; Potentia; Legal theory

\section{A. Introduction}

While events such as the COVID-19 pandemic, Brexit, and the ongoing undermining of the rule of law in several Member States are widely reported and commented upon in the media and academia as challenges that will define the EU for the time to come, an equally critical moment is passing almost unnoticed: For the first time in its history, the EU is in the process of acquiring significant and genuine permanent operational powers. With the inception of Frontex, the EU has been increasingly expanding the powers of the agency, also called the European Border and Coast Guard ("EBCG"). But the new Regulation on the EBCG, adopted by the European Parliament with a large majority, is undoubtedly the apex in this development. ${ }^{1}$ The new Regulation provides the

For invaluable comments on this Article, including earlier versions that only dealt with operational powers in general and not with Frontex' operational powers, I want to thank Veit Bader, David Dyzenhaus, Mariana Gliakti, Serge Gutwirth, Alon Harel, Tormod Otter Johansen, Andreas Moberg, Gregor Noll, Paul Quinn, Jorrit Rijpma, Assaf Sharon, Ingo Venzke and Marc de Wilde. I also received helpful comments from anonymous referees of this journal and the European Law Journal

${ }^{1}$ Regulation 2019/1986 of Nov. 13, 2019, on the European Boarder and Coast Guard and Repealing Regulations (EU) 1052/2013 and (EU) 2016/1624, 2019 O.J. (L 295) 1 [hereinafter Regulation 2019/1896]. On April 17, 2019, the European Parliament adopted at first reading the Proposal by 403 to 162 with 44 abstentions, see Results of Votes, European Parliament (Apr. 17, 2019) https://www. europarl.europa.eu/doceo/document/PV-8-2019-04-17-VOT_EN.pdf. The Council gave its political approval on April 1, 2019, see 
EBCG with a permanent corps of 10,000 border guards, its own equipment, and its own competences to directly intervene along the borders of the EU and beyond.

This Article argues that the conferral of operational powers on the EU, namely the EBCG, poses a risk to individual legal protection. Operational powers are defined as the factual power to physically intervene in tangible reality. In the context of border control, this may include, among other things patrolling, making arrests, providing medical care, taking fingerprints, saving persons from drowning, pushing back a vessel, discharging a firearm, et cetera. Neither Members of Parliament ${ }^{2}$ nor legal experts who are critical of the new Regulation, Frontex, and the EU border management in general, have identified the build-up of EU operational powers as a challenge to legal protection in and of itself. Certainly, since the inception of Frontex, experts in EU migration law have been concerned about the actual and potential unlawful use of powers by Frontex, including operational powers. They have accordingly proposed legal mechanisms that constrain the exercise of operational powers. Yet, their exclusive focus on the exercise of operational powers has left a blind spot. This Article claims that public law should not only constrain the exercise of operational powers, but also provide substantive legal norms constraining the build-up of operational powers. The reason for this is that once authorities have acquired operational powers of a certain extent and quality, they can afford to rule against or without the law by simply overpowering or eluding the legal mechanisms that normally constrain the exercise of public power.

To be clear, there are legal norms that govern the build-up of operational powers. The right of the legislature to approve the budget is probably the quintessential legal norm in this respect. But the existing legal norms are merely procedural. Today there are no legal norms that place substantive constraints on the build-up of operational powers in order to limit the inherent risk that operational powers pose to individual legal protection. This Article will argue that an adapted version of the precautionary test would be a promising candidate for such a substantive constraint. By the same token, this Article only calls for placing constraints on the build-up of operational powers. It does not argue for an outright ban on the conferral of operational powers on the EU, particularly the EBCG.

The Article starts with a description of operational powers as potentia in Section B, taking a cue from the political philosopher Michael Oakeshott and the public administration scholar Christopher Hood. Section C will show how, to date, the EU still lacks operational powers as potentia and how the new Regulation brings a true paradigm shift in this respect. It will also discuss how experts in EU migration law are critical about how the EBCG may exercise operational powers. Still they do not look at the build-up of operational powers. In Section D, I will explain why operational powers may compromise individual legal protection and that legal experts must also explore legal ways to constrain the build-up of operational powers. Section E highlights central aspects of Western legal thought in order to explain why, to date, legal experts have overlooked the build-up of operational powers. This section will also discuss several legal

\footnotetext{
Council 8354/19 (Apr. 9, 2019) https://data.consilium.europa.eu/doc/document/ST-8354-2019-INIT/en/pdf. The adopted proposal was a slightly adapted version of the initial Commission proposal of September 2018, see Commission Proposal for a Regulation of the European Parliament and of the Council on the European Border and Coast Guard and repealing Council Joint Action $n^{\circ}$ 98/700/JHA, Regulation (EU) $n^{\circ}$ 1052/2013 of the European Parliament and of the Council and Regulation (EU) $n^{\circ} 2016 / 1624$ of the European Parliament and of the Council, COM (2018) 631 final (Sept. 12, 2018) [hereinafter Commission Proposal 2018]. Thus, the Regulation passed through the legislative process in record time and without resistance. For an immediate commentary on the day the European Parliament adopted the new Regulation, see Mariana Gkliati, The New European Border and Coast Guard: Do Increased Powers Come With Enhanced Accountability?, (Apr. 17, 2019), http://eulawanalysis.blogspot.com/2019/04/the-new-european-border-andcoast-guard.html. For the commitment of the actual budget to build the standing corps, see European Commission Press Release, 2020 EU Budget: Council Supports Continued Focuse on Growth, Innovattion, Security and Migration (Sept. 3, 2019) https:/www.consilium.europa.eu/en/press/press-releases/2019/09/03/2020-eu-budget-council-supports-continued-focus-on-growthinnovation-security-and-migration/. For the recruitment of their own border guards, see also FRONTEX, EUROPEAN BORDER AND COAST GuARD AgENCY, (“We are recruiting Frontex border guard.”), https://frontex.europa.eu/ (last visited Oct. 24, 2019).

${ }^{2}$ See Sitting of 2019-04-17, European Parliament (Apr. 17, 2019, 3:00pm) http://www.europarl.europa.eu/ep-live/en/ plenary/video?debate $=1555506060624$ (showing the oral interventions by MEPs voting against the new Regulation at the plenary session of April 17, 2019).
} 
arrangements from international and European law that may function as precursors to possible substantive legal constraints on the conferral of operational powers on the EBCG.

\section{B. Operational Powers, Executive Powers, and Potentia}

For this Article, I define operational power as the physical capacity to intervene directly in tangible reality. It is the power of public authorities to carry out physical activities other than legislating, deciding cases, or policy-making. I draw on Michael Oakeshott and Christopher Hood for this understanding of operational powers. In his lecture on the characteristics of the modern European state, Oakeshott uses the notion of potentia to capture "the actual physical power a modern government disposes [of]."3 Oakeshott provides an illustrative list of items that are part of this physical power: Civil, police, and military personnel; records and card systems; passports and border controls; information channels; standardized language, maps, and time measures; telecommunication networks; effective tax collection, and so forth. ${ }^{4}$ In short, Oakeshott refers to all the human resources, infrastructure, equipment, and information that allow states "to control men and things." ${ }^{5}$ More analytically, the public administration scholar Hood, later together with Helen Margetts, distinguishes four tools that governments may use to pursue their policies: Nodality, authority, treasure, and organization. ${ }^{6}$ Nodality refers to information and communication tools such as information about subjects, events and policies, public statements, information campaigns, non-mandatory recommendations, and propaganda. Treasure refers to the financial and monetary capacity. ${ }^{7}$ Authority means legal power, for example, "the power officially to demand, forbid, guarantee, adjudicate." Finally, organization is the physical ability to act directly: "Organization denotes the possession of a stock of people with whatever skills they may have (soldiers, workers, bureaucrats), land, buildings, materials, computers and equipment, somehow arranged." In this Article, I will concentrate on the physical aspects of potentia and organization - the corps of officials and infrastructure, including equipment. A crucial characteristic of operational powers as potentia and organization is that the operational capacity is fully and exclusively at the disposal of the public authorities. ${ }^{9}$ For example, if an authority only has coordinating

\footnotetext{
${ }^{3}$ See Michael Oakeshott, The Character of a Modern European State, in Lectures In The History Of Political Thought 369 (Luke Sullivan \& Terry Nardin ed., 2006).

${ }^{4}$ Id. at 369-71; Michael Oakeshott, On the Character of a Modern European State, in ON Human ConduCT 194-95 (Michael Oakeshott ed., 1975) (failing to call it potentia).

${ }^{5}$ See Oakeshott, supra note 3 , at 370 .

${ }^{6}$ Christopher Hood \& Helen Margetts, The Tools of Government in the Digital Age 6 (Colin Fudge \& Robin Hambleton eds., 2007). I want to thank Paul Quinn for pointing me towards the work of Hood.

${ }^{7}$ See also Terence Daintith, Legal Analysis of Economic Policy, 9 J. L. \& Soc'Y 191, 211-17 (1982); Id. at 213:

Force is seen as dangerous in itself, and the purpose of the constitutional requirement of legislative consent is to protect the subject against the oppressive ruler. Wealth, however, with the exception of its use to maintain armies, always the subject of a specially strict Parliamentary scrutiny, is seen as in principle benign, and the purpose of requiring legislative consent is not to protect the subject against its oppressive use but to protect the collective interests of the taxpaying public against its improvident use.

Hood's notion of treasure corresponds with what Daintith calls "dominium," which involves the deployment of wealth. Daintith calls "imperium" the deployment of public force or threat of force. Imperium partially corresponds with organization, potentia or operational powers because imperium is limited to coercive operational powers only. Though Daintith does not address operational powers sense large, coercive and non-coercive powers, he gives us a hint why the build-up of non-coercive operational powers have been overlooked by legal scholars- they are considered benign.

${ }^{8}$ Oakeshott's potentia seems to include both nodality and treasure.

${ }^{9}$ This distinguishes the late modern state from ancient régime princes whose officials were mostly only in theory agents of the prince but, in reality, acted independently from him. See Luca Mannori \& Bernardo Sordi, Science of Administration and Administrative Law, in A Treatise of Legal Philosophy and General Jurisprudence. Vol. 9: A History of the Philosophy of Law in the Civil Law World 1600-1900 233-34 (Damiano Canale, Paolo Grossi \& Hasso Hofmann eds., 2009).
} 
powers but does not have its own corps of officials that can act physically, it lacks genuine operational powers for the purposes of this Article.

Both Hood and Oakeshott make clear that operational powers must be distinguished from legal powers. Hood contrasts organization with authority, while Oakeshott contrasts potentia with potestas. Operational powers are really about what Hohfeld called the "physical . . . capacity to do a thing," which he clearly distinguishes from legal powers. ${ }^{10}$ Of course, operational powers and legal powers are connected. The build-up and exercise of operational powers must be authorized by and in compliance with the law. Yet, the nature of the two powers is categorically different, which is not merely relevant for analytical or conceptual reasons. In section D, I will argue that the physical or factual nature of potentia poses particular challenges to individual legal protection.

Operational powers include the powers to take coercive and intrusive actions, the so-called executive powers, typically associated with authorities acting manu militari. But operational powers are broader than executive powers as they include the capacity to physically act, whether coercive or not. Also, operational powers include equipment and infrastructure to be used for coercive and non-coercive purposes. Operational powers may be more limited than executive powers if one interprets executive powers in a very broad sense to include the excutive's special regulatory powers - such as the ability to declare a state of emergency. I interpret operational powers to be limited to the capacity to perform factual actions as opposed to legal acts.

Any policy area could serve as an example to illustrate the various manifestations of operational powers as potentia. For instance, in September 2015, in order to stop refugees from entering their territory, the Hungarian authorities adopted a new border policy. ${ }^{11}$ The Hungarian authorities used their legal power to establish the new border regime by issuing legal directives, such as new laws criminalizing illegal border crossings and legal decisions rejecting individual asylum applications. Another crucial legal directive was the ability to declare a state of emergency along the border, thereby enabling the military to be mobilized. Apart from issuing legal directives, the new border regime was put in place by physical actions. Officials erected fences and ensured the physical closure of border crossings. ${ }^{12}$ This capacity to physically do things constitutes operational powers as potentia. So having personnel that can erect the fence and patrol the borders is a crucial element of potentia. Once erected, the border fence itself becomes part of the infrastructure and, thus, an element of operational powers as potentia.

This Article concentrates on the build-up of operational powers. This refers to the process whereby actual physical capacity is put at the disposal of the authorities. It is often a complex legal process that includes the following steps: i) Assignment of tasks to an existing or a newly created public authority; ii) statement that the authority will have resources to perform its tasks; iii) allocation of budget to acquire resources; and iv) public procurement and recruitment. In this Article, I argue that this process of building up operational powers must be subject to legal constraints. I have in mind a special kind of legal constraint—namely legal standards that aim to limit or mitigate the risks that operational powers inherently pose to the protection of individuals. I propose that at the second and third steps, legislators create an adapted precautionary test mapping the risks for legal protection associated with the size and quality of the operational powers that the legislator wishes to allocate to the authorities.

To be clear, I do not suggest that there are no legal constraints already applicable to the buildup of operational powers. Of course, the process itself is subject to constitutional and administrative law. And not only procedural norms but also substantive legal norms are applicable. For example, the actual assignment of tasks to authorities must be in conformity with the law in

\footnotetext{
${ }^{10}$ Wesley Hohfeld, Some Fundamental Legal Conceptions as Applied in Judicial Reasoning, 23 YALE L.J. 16, 24, 44 (1913).

${ }^{11}$ Hungary: New Border Regime Threatens Asylum Seekers, Human Rights Watch (Sept. 19, 2015), https://www.hrw.org/ news/2015/09/19/hungary-new-border-regime-threatens-asylum-seekers (last visited May 8, 2021).

${ }^{12}$ Patrick Kingsley, Refugees Scramble for Ways Into Europe as Hungary Seals Borders, THE GUARDIAN (Sept. 15, 2015), https:// www.theguardian.com/world/2015/sep/15/refugees-scramble-fortress-europe-hungary-seals-borders (last visited May 8, 2021).
} 
general, including human rights. It will be unlawful to assign factual tasks that amount to human rights violations. Similarly, the allocation of actual operational powers-for example, personnel and equipment-must be in conformity with the law. In the context of the new EBCG Regulation, the EU legislature conducted the standard subsidiarity and proportionality tests and inserted a human rights paragraph in the explanatory memorandum. Yet, these existing legal constraints or procedures do not suffice for our purposes. First, the human rights paragraph is only a commitment to human rights. At best, it constitutes an assertion on behalf of the EU that the operational tasks assigned to the EBCG do not amount to human rights violations. ${ }^{13}$ Second, the proportionality test only checks whether the powers granted to the EBCG are proportionate to the objectives of the Regulation. ${ }^{14}$ The EU legislature did not conduct an assessment of the risks of abuse that are associated with the size and nature of the operational powers to be allocated. In other words, this Article distinguishes between the conferral of the legal competence to perform factual tasks and the conferral of the factual capacity to perform the tasks. Both steps are crucial, but legal scholars have focused exclusively on the conferral of the legal competence to perform factual acts and have left unattended the conferral of the factual capacity to do so.

This Article is prompted by the new EBCG Regulation and concentrates on the operational powers of the EU. The analyses in this Article may also apply to operational powers of the Member States. Yet, the supremacy of national parliaments in determining the size and quality of operational powers is so deeply engrained in the constitutional and political make-up of the Member States that any proposal to place legal constraints on the build-up of operational powers at the domestic level is simply unfeasible. By contrast, at the EU level, it is far from evident that the EU may acquire significant operational powers. That is precisely why the new Regulation may turn out to be such a historical moment for the EU. Neither is it evident that, contrary to national parliaments, the European Parliament should have an unfettered right to grant the EU operational powers. In effect, when the various media will pick up on the topic of the EU acquiring significant operational powers, we may expect strong resistance from various political forces within the Member States. To increase its legitimacy, the EU may even have a direct interest in imposing on itself legal constraints on the build-up of operational powers. In other words, while placing legal constraints on the build-up of operational powers at the domestic level is unfeasible, there is a clear window of opportunity to do so at the EU level.

\section{EU Operational Powers and the EBCG \\ 1. Operational Powers of the EU}

At first glance, the EU has all four tools of government defined by Hood at its disposal. Its most prominent tool is undoubtedly authority. This authority encompasses secondary EU legislation such as Regulations and Directives as well as individual decisions by the EU Commission and agencies. Another key instrument of the EU's legal authority is the rulings by the Court of

\footnotetext{
${ }^{13}$ Commission Proposal 2018, supra note 1, at 12 ("All activities of the European Border and Coast Guard, as regards both the European Border and Coast Guard Agency and the Member States' authorities competent for management of borders and return shall be carried out in full respect of fundamental rights as enshrined in the Charter.").

${ }^{14}$ Commission Proposal 2018, supra note 1, at 11 (emphases added):

The proposal is intended to respond to the new challenges and political realities faced by the Union, both as regards migration management and internal security. ... It ensures that rules on integrated border management are fully and correctly implemented by Member States in line with one coherent multiannual strategic policy cycle, that appropriate action is taken to prevent crisis situations and to respond effectively at an early stage at the external borders if such a situation arises and it is only when the situation becomes more critical, that urgent action is taken at Union level for direct intervention on the ground. In view of its objectives and in accordance with the principle of proportionality, as set out in Article 5 of the Treaty on European Union, this Regulation does not go beyond what is necessary in order to achieve those objectives.
} 
Justice of the European Union (“CJEU”). Legal authority as the EU's most formidable tool of government corresponds with the picture of the EU as primarily a legal order and vehicle. Still, from its inception, treasure played a key role in the European project. Probably the largest use of treasure by the European Community ("EC") and EU in the last century was the distribution of subsidies for the Common Agricultural Policy. ${ }^{15}$ Also, the allocation of Structural Funds to support the economic growth of particular regions and economic sectors within the Member States is an instance of treasure. In this century, an impressive display of treasure has been the European Central Bank's program of buying up bonds from commercial banks in order to lower overall interest rates, so-called quantitative easing. The ECB and the Commission used treasure in the context of the financial and Euro crisis when it borrowed money on the financial markets guaranteed by the EU budget in order to issue loans to the Member States in financial difficulty-especially under the European Financial Stability Mechanism. ${ }^{16}$ Nodality, as in sending and collecting information, has been a key tool of government for the EU. The EU has a long tradition of setting up public information campaigns and specialized public relations offices. It established its own information collection capacity through the various specialized departments and agencies. It has its own statistics bureau, Eurostat, and it also runs its own databases, for example, Europol Information System, Schengen Information System, European Publication Server, and European Patent Register. In terms of organization, the EU tools are equally substantial. Apart from buildings and equipment, the EU has a corps of 55,000 permanent, trained, paid, and loyal civil servants at its disposal. ${ }^{17}$

Adding up all these tools of government, one may conclude that, similar to the modern European states as described by Oakeshott, the EU possesses potentia. Yet, one thing is missing in the EU context. The EU still lacks the physical ability to act directly. Of course, its own officials perform acts involving nodality, authority, and treasure. But when it comes to actual physical acts, especially those involving forms of coercion, the EU has to rely on the civil and military servants of the Member States. ${ }^{18}$ The EU is not an administrative state performing tasks remotely like the administration of the Member States. ${ }^{19}$ The EU by itself cannot act physically. Although the values and policy objectives make the EU a truly twentieth-century project, its central mode of governance throws it back to the ancien régime-a central authority completely dependent on the cooperation of local officials over whom it does not have direct and effective authority. ${ }^{20}$

\section{Operational Powers of the EBCG}

Ever since the management of the European borders became a matter of EU policy, the Commission envisaged a truly integrated European border management with a corps of EU border guards. ${ }^{21}$ The Member States, however, refused the outright establishment of a genuine

\footnotetext{
${ }^{15}$ See Fact Sheets on the European Union, European PARLIAMENT, http://www.europarl.europa.eu/atyourservice/en/ displayFtu.html?ftuId=FTU_5.2.2.html (last visited May 1, 2021).

${ }^{16}$ See How Does the EU Finance its Financial Assistance?, EUROPEAN COMMISSION, https://ec.europa.eu/info/business-economyeuro/economic-and-fiscal-policy-coordination/eu-financial-assistance/loan-programmes/how-commission-finances-eu-financialassistance-programmes_en (last visited May 1, 2021).

${ }^{17}$ EU Administration- Staff, Languages and Location, EUROPEAN UNION, http://europa.eu/about-eu/facts-figures/ administration/index_en.htm (last visited May 1, 2021).

${ }^{18}$ For example, the EU Aid Volunteers who make up the European Medical Corps are merely contractors and not considered to be EU staff. See Regulation 375/2014 of Apr. 3, 2014, Establishing the European Voluntary Humanitarian Aid Corps ('EU Aid Volunteers initiative'), 2014 O.J. (L 122), at arts. 14(5-6).

${ }^{19}$ Some exceptions are the educational institutions run by teaching staff employed by the EU.

${ }^{20}$ Sophie Robin-Olivier, The Evolution of Direct Effect in the EU: Stocktaking, Problems, Projections, 12 INT'L. J. CONST. L. 165, 187 (stating in effect, "EU law executive force is contingent on the situation of each national legal system.").

${ }^{21}$ Communication From the Commission to the Council and the European Parliament Towards Integrated Management of the External Borders of the Member States of the European Union, COM (2002) 233 final 22 (May 7, 2002). For a historical overview of the legal and institutional framework of the EU border policy and a description of the actual border operations, see Jorrit Rijpma, Frontex and the European System of Border Guards: The Future of EuropeanBorder Management, in THE
} 
European border guard because border control is perceived to be one of the few remaining competences expressing national sovereignty. ${ }^{22}$ By the same token, the Member States did not oppose the gradual and continuous expansion of the agency's tasks, competences, and resources that stemmed from the establishment of Frontex in 2004. ${ }^{23}$ The expansion of powers reached a new milestone with the 2016 Regulation transforming Frontex into the EBCG-hereafter the 2016 Regulation. ${ }^{24}$ At its official launching event at the Kapitan Andreevo Border Checkpoint between Bulgaria and Turkey, the EBCG proudly presented its vehicles, equipment, and border guard teams. At the event, the Migration, Home Affairs, and Citizenship Commissioner Dimitris Avramopoulos announced: "From now onwards, the external EU border of one Member State is the external border of all Member States-both legally and operationally. In less than one year we have established a fully-fledged European Border and Coast Guard system." ${ }^{25}$ Let us take a closer look at the powers so far granted to the EBCG and gauge whether it possesses operational powers as potentia. I will concentrate on the operational powers of the EBCG in terms of human resources, modes of deployment, and infrastructure.

The EBCG has seen an increase of its staff from forty-five in 2005 to 488 in $2017 .{ }^{26}$ However, these staff members work mainly out of the Warsaw headquarters conducting analyses, making operational plans, and coordinating operations. The staff members are not factually executing the actual border operations. By contrast, the 2016 Regulation provided for a rapid reaction pool of 1,500 border guards at the disposal of the EBCG permanently. ${ }^{27}$ Prior to this rapid reaction pool, Frontex worked with border guards that were assigned to specific operations by the Member States. The pool of 1,500 border guards is made available for deployment in operations that fall outside the normal annually planned operations to which the Member States contribute and assign border guards. ${ }^{28}$

Under the 2016 Regulation, the rapid reaction pool could be deployed in two scenarios: Rapid interventions and situations at the external borders requiring urgent actions. The rapid interventions are triggered by a Member State's request facing "a situation of specific and disproportionate challenges." ${ }^{29}$ The 2016 Regulation envisaged two situations that may require urgent action. Either a Member State failed to implement the necessary measures ordered by the Agency following recommendations from the Agency in the context of a vulnerability assessment ensuring adequate border control..$^{30}$ Or a Member State was facing specific and disproportionate challenges at the external borders but failed to request support from the Agency-whether that be from the Agency's joint operation, rapid border intervention, or border management support teams.

European Union as an Area of Freedom, Security and Justice 217-28, 233-35 (Maria Fletcher, Ester Herlin-Karnell \& Claudio Matera eds., 2017); Seline Trevisanut, Which Borders for the EU Immigration Policy? Yardsticks of International Protection for EU Joint Borders Management, in EU Migration LaW: Legal Complexities and Political Rationales 106-22 (Loïc Azoulai \& Karin de Vries eds., 2014).

${ }^{22}$ Mariana Gkliati, The Next Phase of the European Border and Coast Guard: Towards Operational Effectiveness, EU LAW ANALYIS (Oct. 8, 2018), http://eulawanalysis.blogspot.com/2018/10/the-next-phase-of-european-border-and.html (last visited May 8, 2021).

${ }^{23}$ Rijpma, supra note 21, at 220. For the remarkably swift legislative processes expanding the powers of Frontex, see also Sergio Carrera, Steven Blockmans, Jean-Pieree Cassarino, Daniel Gros \& Elspeth Guild, The European Border and Coast Guard: Addressing Migration and Asylum Challenges in the Mediterranean? 43 (2017).

${ }^{24}$ Regulation 2016/1624 of Sept. 14, 2016, on the European Border and Coast Guard, and Amending Regulation (EU) 2016/ 399 of the European Parliament and of the Council and Repealing Regulation (EC) 863/2007 of the European Parliament and of the Council, Council Regulation (EC) 2007/2004 and Council Decision 2005/267, 2016 O.J. (L 251) 1 (EC) [hereinafter Regulation 2016/1624 or 2016 Regulation].

${ }^{25}$ Press Release, European Commission, Securing Europe's External Borders: Launch of the European Border and Coast Guard Agency (Oct. 6, 2016), http://europa.eu/rapid/press-release_IP-16-3281_en.htm. (last visited May 8, 2021).

${ }^{26}$ See Gliakti, supra note 22.

${ }^{27}$ Regulation 2016/1624, supra note 24, at art. 20(5).

${ }^{28} \mathrm{Id}$. at art. $20(4-5)$.

${ }^{29}$ Id. at art. $15(2)$.

${ }^{30} I d$. at arts. 1, 6, 8, 19(1a). 
Still, they failed to implement the actions required under such support operations. ${ }^{31}$ In other words, the Member State failed to take the necessary steps to ensure adequate border controls. And thus, the EU had to step in.

When deployed in operations run by the EBCG, the border guards were authorized to perform all the operational and factual actions associated with border guard operations, including carrying service weapons, the use of force, and ultimately the use of service weapons and ammunition in the event of legitimate self-defense and the defense of team members. ${ }^{32}$ Furthermore, the EBCG acquired its own equipment to be deployed during its operations. ${ }^{33}$

At first glance, under the 2016 Regulation, the EBCG acquired genuine operational power as potentia: The EBCG has border guards, equipment, and the competence to deploy them. In effect, according to the Commission, in September 2017, the EBCG deployed over 1,700 border guards and other staff at the EU's external borders. ${ }^{34}$ So it seems that the EU Commissioner was not exaggerating when referring to the EBCG as a fully-fledged border and coastguard system. Yet, upon closer scrutiny, the EBCG still lacked genuine operational powers as potentia. First, the border guards, including members of the rapid reaction pool, were not officials of the Agency. They were not hired and fired by the Agency, but rather seconded by the Member States. Most importantly, they were not under the authority or instructions of the Agency. The border guards could only act under instructions from, and as a general rule in the presence of, border guards of the host Member State. ${ }^{35}$ Second, the EBCG could not deploy the border guards, not even the 1,500 from the rapid reaction pool, without the consent of the Member States. Even operations in the event of an urgent action depended on the consent of the Member State concerned. The urgent action was not ordered by the Agency or the Commission, but by the EU's political body, namely the Council. The Member State concerned still had a say in the Council and, with the help of political allies, could block the decision. Moreover, the actual implementation of an urgent action required an operational plan on which the Member State concerned must agree. ${ }^{36}$ Therefore, without the consent of the Member State, the EBCG could not conduct operational actions. Finally, as to potentia in terms of infrastructure, although on paper the EBCG could acquire operational assets of its own, this has remained limited to a dedicated budget of $€ 40$ Million for small and medium-sized equipment. ${ }^{37}$

While under the previous 2016 Regulations, the EBCG did not have true operational powers as potentia, this is completely changed with the new Regulation. In effect, one of the most spectacular aspects of the new Regulation is the standing corps of 10,000 border guards and operational staff. ${ }^{38}$ The standing corps is made up of four categories of staff members: Staff members of the Agency itself, operational staff seconded by the Member States for a long term deployment, staff members provided by the Member States for a short-term deployment, and operational staff from the Member States for a Reserve for Rapid Reaction up to the year $2024 .{ }^{39}$ The share of the

\footnotetext{
${ }^{31}$ Id. at art. $19(1 \mathrm{~b})$.

${ }^{32}$ These powers were already granted to the border guards under Regulation 863/2007, of the European Parliament and of the Council of 11 July, 2007, Establishing a Mechanism for the Creation of Rapid Border Intervention Teams and Amending Council Regulation 2007/2004 (EC) as regards that mechanism and regulating the tasks and powers of guest officers, 2007 O.J. (L 199) 31, art. 6 (EC); see Regulation 2016/1624, 2016 O.J. (L 251) 1, arts. 40(1), 40(5-7).

${ }^{33}$ Regulation 2016/1624, supra note 24, at art. 38(1).

${ }^{34}$ Communication From the Commission to the European Parliament, the Council, the European Economic and Social Committee and the Committee of the Regions on the Delivery of the European Agenda on Migration, at 11, COM (2017) 558 final. (Sept. 27, 2017). It is not clear what part of those border guards were deployed from the rapid intervention pool.

${ }^{35}$ Regulation 2016/1624, supra note 24, at arts. 21(1), 40(3).

${ }^{36} \mathrm{Id}$. at art. 19(4-5).

${ }^{37}$ Explanatory Memorandum, Commission Proposal 2018, supra note 1, at 15

${ }^{38}$ Regulation 2019/1896, supra note 1 , at art. 54(1), annex I.

${ }^{39}$ The Commission Proposal 2018 did not have a fourth category of border guards. Instead, it proposed a larger contingent of category 2 long-term secondment staff-namely 3,000 in 2027, see Commission Proposal 2018, supra note 1, at art. 55.1.
} 
Agency's officials will increase from 1,000 in 2021 to 3,000 in 2027. ${ }^{40}$ The Agency's operational staff members will have the full status of EU officials governed by the EU Staff Regulations and Conditions of Employment. ${ }^{41}$ The Agency's operational staff members will thus fall under the disciplinary authority of the EBCG and not under the authority of a Member State. Just like under the former 2016 Regulation, the new Regulation grants the operational staff full executive powers such as identity checks, taking fingerprints, patrolling, carrying and using firearms, and legal powers such as entry refusals and the issuing and refusing of visas at the border. ${ }^{42}$

Furthermore, whereas under the 2016 Regulation the rapid reaction pool is to be deployed only in exceptional unplanned operations, the point of the standing corps is to ensure the effective conduct of regular operations. ${ }^{43}$ The standing corps is meant to address the structural understaffing of regular Frontex operations as Member States fail to contribute sufficient qualified operational staff to the EBCG. In other words, the new Regulation seeks permanent deployment of the Agency's own operational staff in regular operations that are initiated by the Member States, such as joint operations, rapid border interventions, and operational reinforcement. ${ }^{44}$ Furthermore, similar to the previous Regulation, operations may be initiated by the Agency. When there is a situation requiring urgent actions, the standing corps may be deployed. ${ }^{45}$ When such actions are taken, the concerned Member State must comply with the measures. ${ }^{46}$ If not, the Council may trigger the procedure for reintroducing internal border control at the borders of the concerned Member State. ${ }^{47}$ However, in line with the 2016 Regulation, a concerned Member State can still prevent the deployment of the standing corps because, under the new Regulation, it is not the Commission but the Council who decides to take urgent action. The Council, based on a proposal by the Commission and after consultation with the Agency, may decide to take urgent action. ${ }^{48}$ At the level of the Council, the concerned Member State, or any other Member State, can block the decision to take urgent action. Thus, while under the new Regulation the EU has the power to deploy its own operational staff, it can only do so with the indirect consent of the Member States.

As opposed to the border guards that are provided and seconded by the Member States, the Agency's own border guards do not fall per se under the jurisdiction of a Member State. When the Agency's border guards act in their official capacity, they shall be immune from legal proceedings pursuant to Article 11 of the Protocol (No. 7) on the Privileges and Immunities of the European Union, following Article 96 of the new Regulation. The text of the new Regulation is confusing in this respect. Pursuant to Article 85 of the new Regulation, "statutory staff, shall be treated in the same way as officials of the host Member State with regard to any criminal offenses that might be committed against them or by them." ${ }^{9}$ The former 2016 Regulation provided the same form of criminal liability for seconded personnel of Frontex. The difference is now Frontex also has its own statutory staff. So, at first glance, Frontex's border guards are not exempted from criminal

\footnotetext{
${ }^{40}$ Regulation 2019/1896, supra note 1, at arts. 54(1), annex I.

${ }^{41}$ Regulation 2019/1896, supra note 1, at arts. 54(1), 95(1).

${ }^{42}$ Contrary to the Commission Proposal 2018 under the new Regulation Agency staff will only carry and use weapons when the executive director provides them with the entitlement to do so. See Regulation 2019/1896, supra note 1, at arts. 54(3), 55(7), 82 , \& annex V.

${ }^{43}$ Explanatory Memorandum, Commission Proposal 2018, supra note 1, at 3-5.

${ }^{44}$ Regulation 2019/1896, supra note 1, at arts. 36(2), 37, 40.

${ }^{45} I d$. at art. $42(3 \mathrm{~b})$.

${ }^{46} I d$. at art. $42(8)$.

${ }^{47}$ Id. at art. 42(10); see also Schengen Borders Code, infra note 110 at art. 29.

${ }^{48}$ The Commission Proposal 2018 granted the authority to decide not to the Council, but to the Commission after consulting the Agency. In other words, the Commission Proposal gave the EU the power to deploy border guards without the indirect consent of a Member State concerned. The parliamentary Rapporteur curtly dismissed this proposition, see Plenary Sitting 12 February 2019, A8-0076/2019, Eur. PARL. Doc. (COM 063) final 238 (2019) http://www.europarl.europa.eu/doceo/ document/A-8-2019-0076_EN.pdf ("The Rapporteur also considers that there is no reason to move away from the agreement reached with the Council EBCG 1.0 in 2016 on the situation at the external borders requiring urgent action."), at 238.

${ }^{49}$ Regulation 2019/1896, supra note 1, at art. 85.
} 
liability. However, Article 85 states that the possible criminal liability of statutory staff is "without prejudice to Art. 95" of the new Regulation. The reference to Article 95 seems like a typographical error-instead of Article 95, it should read Article 96. Article 95 deals with the conditions of employment of statutory staff, which are a matter completely unrelated to the criminal liability of statutory staff as addressed in Article 85. By contrast, Article 96 makes Protocol No. 7 on the Privileges and Immunities of the European Union annexed to the Treaty on European Union ("TEU") and the Treaty on the Functioning of the European Union ("TFEU") applicable to the Frontex statutory staff. As a result, Frontex's statutory staff will benefit from the same immunities as EU servants and thus will "be immune from legal proceedings in respect of acts performed by them in their official capacity." According to Article 17 of the Protocol, this immunity is not absolute because the EU is required to waive the immunity wherever it considers such waiver not to be contrary to the interests of the Union.

How then should we read Article 85 of the new Regulation? To me, it seems that the immunity for criminal proceedings is the default for Frontex statutory staff. Whenever Frontex, or another competent EU institution, waives the immunity of a particular Frontex border guard, that border guard will be treated in the same way as officials of the host Member State. Thus, when the immunity of a Frontex border guard has been waived, the border guard can be prosecuted as if he were a border guard of the host Member State.

Finally, the new Regulation seeks to ensure that the EBCG acquires substantial operational assets of its own, allowing it to conduct operations without the need to rely too much on equipment and voluntary contributions from the Member States. ${ }^{50}$ To this end, the new Regulation provides for a technical equipment pool and the obligation to establish a multiannual strategy for the build-up of the Agency's operational assets. ${ }^{51}$ Also, the Agency's operational assets will include not only small and medium-sized equipment, but also major technical equipment such as aircraft, helicopters, and vessels. ${ }^{52}$

In short, for the first time in history, the new Regulation will grant the EBCG, and by extension the EU, genuine, substantial operational powers in terms of its own human resources, technical equipment, and competence to deploy the operational powers. ${ }^{53}$

\section{The Views of Legal Experts on the EBCG Having Operational Powers}

Legal experts have been critical of Frontex from its inception. Part of their concern is the way Frontex exercises its powers, including operational powers. Clearly, Frontex's operational powers are a matter of concern for legal experts, especially Frontex's capacity to prevent human rights violations. ${ }^{54}$ There is, however, a blind spot in the otherwise invaluable critical observations by

\footnotetext{
${ }^{50}$ Explanatory Memorandum, Commission Proposal 2018, supra note 1, at 16.

${ }^{51}$ Regulation 2019/1896, supra note 1, at arts. 63, 64.

${ }^{52}$ Regulation 2019/1896, supra note 1, at art. 63(4).

${ }^{53}$ Still, the EU's operational powers will not be completely identical to the operational powers of modern European states as described by Oakeshott, as the EU still depends on the indirect consent of the Member States when deploying its own operational staff. But even under the Commission Proposal 2018, the Member State concerned could technically speaking still immobilize the EBCG's operations by refusing to cooperate. When the Commission decides to take urgent measures, the Agency and the Member State must draw up an operational plan. See Commission Proposal 2018, supra note 1, at art. 43(5). If the Member State does not cooperate, there will be no operational plan, which is the basis for any actual operation. Furthermore, the Member State concerned must issue instructions to the border guard teams in accordance with the operational plan. See Commission Proposal 2018, supra note 1, at art. 44(1). If the Member State concerned does not issue instructions, in accordance with the operational plan, then the Agency may terminate or suspend the operations. See Commission Proposal 2018, supra note 1, at arts. 44(3) \& 47(3). But the Agency may not launch or continue an operation in lieu of the Member State concerned.

${ }^{54}$ See e.g., Joint Briefing on the European Border and Coast Guard Regulation: International Commission of Jurists, ECRE and Amnesty International, https:/www.ecre.org/wp-content/uploads/2016/07/ECRE-Amnesty-ICJ-Joint-Briefing-on-theEuropean-Border-and-Coast-Guard-Regulation_April-2016.pdf (last visited May 6, 2021).
} 
legal experts. Legal experts concentrate on the exercise of operational powers, but not on the buildup of operational powers. In their analyses, the size and quality of the operational powers are not factors relevant for establishing the risk of abuse by Frontex. What matters to the legal experts is how Frontex exercises these powers and whether there are sufficient legal checks, ex-ante or expost, on this exercise. I share their concerns and support most of their solutions, but I find that due to the special nature of operational powers, legal constraints on the exercise of powers are simply not enough. ${ }^{55}$ Let me briefly and schematically reiterate the central concerns of legal experts to clarify this blind spot in the current literature. When it comes to Frontex operations and Frontex having operational powers, experts have roughly three types of concerns: First, the conferral of executive powers on Frontex is unconstitutional; second, many Frontex operations are unlawful; and third, accountability for Frontex operations is lagging.

First, many have challenged the constitutionality of the conferral of executive powers to Frontex. The conferral of executive powers to the EBCG is not provided for in the European Treaties and does not follow clearly from any implied powers. ${ }^{56}$ The constitutional objection against Frontex having operational powers is not so much based on the particular nature of operational powers. It is instead because treaties have not provided for the conferral of such powers. ${ }^{57}$ In other words, the critique is not about the risk of abuse inherently associated with operational powers.

Second, parts of Frontex operations in and of themselves violate existing international law, human rights law, and EU law. For example, extra-territorial pre-entry controls and maritime interdictions may violate the prohibition on non-refoulement, the right to leave one's country, and the duty to process and scrutinize claims for international protection. ${ }^{58}$ Accordingly, important elements of EU border policies, rules, and operations should be adapted or even abandoned. ${ }^{59}$ This critique is not directed at the special nature of operational powers, but at the nature of certain tasks and operations. In other words, the concern is not about possible abuses because Frontex has operational powers, but rather that certain operations constitute abuses. The solution is, therefore, not constraining the operational powers but simply abandoning such operations.

Third, legal experts criticize the lack of adequate accountability mechanisms putting checks on Frontex operations. One reason for the lack of accountability was the fact that under the previous Regulations, it was not a settled matter for the EU that Frontex operations may trigger its liability, precisely because Frontex lacked operational powers of its own and merely coordinated operations under the responsibility of the Member States or Third Countries. ${ }^{60}$ By contrast, the new Regulation allows Frontex to have its own border guards, thereforebecoming directly legally

\footnotetext{
${ }^{55}$ See infra Section D.

${ }^{56}$ Francesca Ferraro \& Emelio De Capitani, The New European Border and Coast Guard: Yet Another "Half Way" EU Reform?, 17 EUROPÄISCHE RECHTSAKADEMIE F. 385, 390-91 (2016); Rijpma, supra note 21, at 237-39; CARRERA ET AL., supra note 23, at 57; Herbert Rosenfeldt, Establishing the European Border and Coast Guard: All-New or Frontex Reloaded?, EU LAW ANALYSIS (Oct. 16, 2016), http://eulawanalysis.blogspot.com/2016/10/establishing-european-border-and-coast.html.

${ }^{57}$ The constitutional critique appears as a marginal and purely academic concern that will not lead to any cases seeking the invalidation of the new Regulation. Even experts advancing the constitutional argument concentrate most of their efforts on discussing substantive issues.

${ }^{58}$ Violeta Moreno-Lax, Accessing Asylum in Europe. Extraterritorial Border Controls under Refugee Rights AND EU LAW Part I (2017).

${ }^{59} \mathrm{Id}$. at $477-78$.

${ }^{60}$ In the absence of direct executive powers, the liability of Frontex for human rights violations may be constructed through Frontex acting in association with Member States that violate positive human rights obligations. See generally MELANIE FINK, Frontex and Human Rights: Responsibility in 'Multi-Actor Situations' Under the ECHR and EU Public Liability LaW (2018); MELANIE FINK, A "Blind Spot" in the Framework of International Responsibility? Third Party Responsibility for Human Rights Violations: The Case of Frontex, in Human Rights AND THE DARK Side of Globalisation: TransNational LAW ENForcement 272-93 (Thomas Gammeltoft-Hansen \& Jens Vedsted-Hansen eds., 2017); MAÏTÉ FERNANDEZ, The EU External Borders Policy and Frontex-Coordinated Operations at Sea: Who is in Charge?, in BOAT REFUGEES AND MIGRANTS AT Sea: A Comprehensive Approach. Integrating Maritime Security with Human Rights 381 (Violeta Moreno-Lax \& Efthymios Papastavridis eds., 2016); Roberta Mungianu, Frontex and Non-Refoulement: The International RESPONSIBILITY OF THE EU Ch. 8 (2016).
} 
responsible for the EU border operations bringing "clarity to the legal twilight within which Frontex currently operates." ${ }^{\prime \prime}$ Of course, this clarity does not mean that the actual procedures and mechanisms in place to monitor, establish, and enforce liability are adequate. For example, under the new Regulation, individual complaint mechanisms and the monitoring powers of the EBCG's own Fundamental Rights Officer ("FRO") are inadequate in terms of the processes, impartiality, and resources of the FRO. ${ }^{62}$ Accordingly, experts propose, inter alia, imposing an EU monitor under the auspices of the EU Ombudsman to "regularly monitor the conditions under which the border operations take place." ${ }^{63}$ To increase accountability, experts also call for more transparency from Frontex even during the planning of operations. ${ }^{64}$ Furthermore, the mechanism of immunity for individual EBCG border guards under the new Regulation is perceived to be highly problematic from a rule of law perspective. ${ }^{65}$ It should be clear that these critical observations and proposals are not aimed at the build-up of operational powers. They do not identify operational powers as posing a risk of abuse of powers in and of themselves. The focus is on the exercise of operational powers and on accountability mechanisms that can put checks on the exercise of operational powers.

Interestingly, when legal experts directly consider the merits of the EBCG having operational powers, many are rather positive. The main reason for this is that they expect the EBCG to do a better job of safeguarding the fundamental rights of migrants during border operations than the border agencies of the individual Member States. ${ }^{66}$ Furthermore, legal experts do not contest the EU's basic assumption that a centralized and fully integrated EU border guard with genuine operational powers will enable the EU to execute border policies more effectively and vigorously than the current fragmented cooperation model of national border agencies, which have varying willingness and capacity to contribute to and participate in border operations. ${ }^{67} \mathrm{I}$ think the experts are right to point out the protective potential of an EU border guard with genuine operational powers. Again, this Article is not an argument against operational powers. But the general picture that emerges from the literature is too one-sided - operational powers are potentially salutary, provided that Frontex implements the ex-post and ex-ante accountability checks on the exercise of these operational powers.

I have found only oblique references to some awareness that the size and quality of operational powers matter in and of themselves. For example, legal experts advocate that the EU border guard should be of a predominantly civilian nature, rather than military. This view relies on the insight

\footnotetext{
${ }^{61}$ Rijpma, supra note 21, at 239.

${ }^{62}$ Ferraro \& De Capitani, supra note 56, at 39-96; Jorrit Rijpma, The Proposal for a European Border and Coast Guard: Evolution or Revolution in External Border Management?, in STUDY FOR THE LIBE COMMITTEE 30-31 (2016); Rosenfeldt, supra note 56, at 6; David Fernández-Rojo, The European Border and Coast Guard: Towards the Centralization of the External Border Management?, BlogActive (Feb. 7, 2017), https://eutarn.blogactiv.eu/2017/02/07/the-european-borderand-coast-guard-towards-the-centralization-of-the-external-border-management/.

${ }^{63}$ CARRERA ET AL., supra note 23, at 58 (referring to Peter Hobbing, The Management of the EU's External Borders: From the Customs Union to Frontex and E-borders, in The AREA of Freedom SECURITY AND JUstice Ten YeARS ON: SUCCESSES AND Future Challenges under the Stockholm Programme 63-72 (Elspeth Guild, Sergio Carrera \& Alejandro Eggenschwiler eds., 2010)).

${ }^{64}$ Mungianu, supra note 60, at 230.

${ }^{65}$ Meijers Committee, CM1817 Comments on the Draft for a New Regulation on a European Border and Coast Guard, COM (2018) 631 final and the Amended Proposal for a Regulation on a European Union Asylum Agency, COM (2018) 633 final, at comt. no. 5 (Nov. 27, 2018), https://www.commissie-meijers.nl/sites/all/files/cm1817_note_ebcg_and_euaa.pdf.

${ }^{66}$ CARrera ET AL., supra note 23, at 48, 56; Cf. A Reinforced Frontex Agency EUTurns a Deaf Ear to NGO's Warnings, Progress LAWYers NeTwOrK (Sept. 22, 2016), https://www.progresslaw.net/assets/files/In-de-pers/ 20160927101302RQZU.pdf (stating activist lawyers warned that more powers to Frontex only means more powers to continue the human rights violations taking place during Frontex operations).

${ }^{67}$ Philippe De Bruycker, The European Border and Coast Guard: A New Model Built on an Old Logic, 1 EUR. PAPERS 559, 568 (2016).
} 
that, by its very nature, a civilian agency is better equipped to conduct operations involving civilian migrants while respecting fundamental rights and the rule of law than a military agency. ${ }^{68}$

Similarly, legal experts criticize the deployment of border guards in hot spots. They argue this puts undue focus on border control at the expense of providing international protection. ${ }^{69}$ This criticism shows that legal experts are aware of the fact that the nature or type of operational powers conferred on the EBCG matters.

Also, the constitutional objection against a conferral of executive powers on the EBCG relies on a distinction between regulatory and executive powers. The exercise of regulatory powers is more susceptible to judicial review by a court, in this case the CJEU, than the exercise of executive powers. The latter are "factual rather than legal and involve a level of discretion that is difficult to regulate." ${ }^{\prime 70}$ As a result, "(j)udicial review [by the CJEU] would not be available for purely factual actions during border checks and surveillance, although the possibility of an action for damages would be open" when the factual actions violate European law. ${ }^{71}$ Arguably, and considering the Meroni doctrine, this impossibility of judicial review by the CJEU makes the conferral of operational powers on the EBCG unconstitutional. There is thus a difference between legal powers and factual powers in terms of being susceptible to effective judicial review and legal protection. Accordingly, factual actions require extensive and precise regulation for a court to conduct a full judicial review. I do not think that the difference between factual actions and legal acts lies in the level of discretion involved. Rather, as I will argue in the next section, it is the physical and concrete nature of factual actions and operational powers that enable authorities to sometimes simply overpower, or elude, normal legal mechanisms offering ex-ante legal protection. That is why legal experts must also concentrate on legal standards constraining the build-up of operational powers.

\section{Legal Protection and Operational Powers}

Legal experts commenting on the EBCG concentrate on legal mechanisms that can constrain the possible unlawful exercise of the EBCG's operational powers. But the central claim of this Article is that these legal constraints on the exercise of operational powers are not enough. There should also be constraints on the build-up of operational powers. This section discusses three reasons why there should be legal constraints on the build-up of operational powers. First, the law can constrain the exercise of public powers to the extent that authorities are interested in governing through law. Legal norms are good at constraining the exercise of legal powers but are less powerful against the exercise of operational powers. Second, operational powers of a certain size and quality enable authorities to overpower or even elude the legal mechanisms that normally protect individuals against the unlawful exercise of operating powers. Third, operational powers, once built up, cannot be easily unwound or undone. Although operational powers are created by the law, namely via the right of budget, the law cannot make them disappear. Existing operational powers tend to be resilient.

\section{1. "Law Constrains Law"}

The law is good at constraining authorities to the extent that authorities use and need the law to govern. This connects to the idea that the rule of law at least requires authorities to rule through law. ${ }^{72}$ Also, the law-like character of a measure taken by authorities is determined by the extent to

\footnotetext{
${ }^{68}$ CARRERA ET. AL, supra note 23, at 56-58 (quoting Sergio Carrera, Towards a Common European Border Service, CEPS WORKING DOCUMENT No. 311 (2010)).

${ }^{69}$ Rijpma, supra note 62, at 19.

${ }^{70} I d$. at 239 .

${ }^{71} I d$.

${ }^{72}$ Neil Walker, The Rule of Law and the EU: Necessity's Mixed Virtue, in Relocating THE Rule OF LAW 122 (Gianluigi Palombella \& Neil Walker eds., 2009) ("The rule of law clearly places a high priority on rule through the modality of law, as
} 
which the measure can be subjected to judicial review. ${ }^{73}$ To put it differently, the law-like nature of a measure and legal protection go hand in hand. Therefore, the more authorities claim that their actions are based on the law and demonstrate their actions in a legal form, the more they subject themselves to the law's constraining forces. But why do authorities govern through law? This is, of course, an immense topic of legal sociology, legal psychology, and political science that is beyond the scope of this Article. ${ }^{74}$ For our purposes, we can limit ourselves to an archetypical communicative scheme that lies at the basis, at least conceptually, of most invocations of law by authorities. ${ }^{75}$ When authorities invoke the law, they claim obedience from subjects. ${ }^{76}$ In doing so, they ask the subjects to cooperate. The cooperation can consist of positive actions, such as offering help and making contributions, or inactions, such as refraining from obstructing or resisting authorities. ${ }^{77}$ If authorities can secure such cooperation, it allows them to govern over subjects and matters that would otherwise remain beyond their reach. In other words, through successful invocations of the law, authorities can get things done which they otherwise could not execute themselves. Also, the law enables authorities to have subjects do things even if the authorities lack the physical capacity to coerce subjects into doing these things. As stated in terms of Christopher Hood's Tools of Government, legal authority can compensate for the lack of organization.

A successful invocation of the law depends on whether subjects believe that the call for obedience is lawful. In other words, by relying on the law, authorities must convince subjects that they respect the law. As a result, the law that enables authorities to govern beyond their physical powers coevally constrains them. This is why the law is good at constraining the use of the law. More technically speaking, by governing through law, the authorities expose themselves to legal challenges. This is a precondition for individual legal protection. The risk of non-cooperation, especially obstruction and resistance, makes it critical for authorities to show that they are acting in

opposed to other modalities of power such as threat, economic incentive or appeal to first order reason.") (emphasis in the original).

${ }^{73}$ See David Dyzenhaus, Accountability and the Concept of (Global) Administrative Law 16 N.Y.U., Working Paper No. 2008/7, 2008 (stating the point of judicial review of administrative decisions "is not that judicial review is what makes the decisions of such bodies [privatized administrative bodies] more law-like, but that what makes them more law-like makes them also fit for judicial review.").

${ }^{74}$ The vast literature on police misconduct comes to mind. Already, a superficial glimpse at the literature shows that explanations for why officials comply or do not comply with the law are highly complex. The size and quality of operational powers are not identified as distinct explanatory factors, but they would typically fall under the organizational and situational explanations for police misconduct. For example, the size of police departments seems to affect the occurrence of police misconduct. See Christopher Donner \& Wesley Jennings, Low Self-control and Police Deviance: Applying Gottfredson and Hirschi's General Theory to Officer Misconduct, 17 POLICE QUARTERLy 203 (2014); Christopher Harris, Police Use of Improper Force: A Systematic Review of the Evidence, 4 Victims \& Offenders: An Int'L J. Evidence-Based Rsch, Pol'y And Prac. 25 (2009); David Eitle, Stewart D'Alessio \& Lisa Stolzenberg, The Effect of Organizational and Environmental Factors on Police Misconduct, 17 Police Quarterly 103 (2014).

${ }^{75}$ For this archetypical scheme, see Christoph Kletzer, Primitive Law, 4 JuRIs.: AN INT'L J. OF LEGAL AND POL. THOUGHT 263 (2013); Bas Schotel, Multiple Legalities and International Criminal Tribunals: Juridical Versus Political Legality, in PolitiCs of Legality in InTernational Law 209-32 (Tanja Aalberts, Thomas Gammeltoft-Hansen \& Nick Rajkovic eds., 2016) (drawing on legal history and on law as autopoiesis proposed by Luhmann and Teubner). But while autopoiesis focuses on the epistemic and communicative function of law, knowing what to legitimately expect from others, according to a "juridical law" understanding the distinctive function of law, is to seek factual cooperation and authorize factual actions. To be sure, this conception of law does not claim that law is only invoked with a view to cooperation. Law may have many functions or uses, for example expressive, coordinative, and epistemic. Yet this conception does claim that seeking cooperation is the distinctive and archetypical use of law on which these other uses of law rely practically and conceptually. So, if actors cease to invoke the law for purposes of seeking active or passive factual cooperation, then arguably the law will also lose its other functions.

${ }^{76}$ This does not mean that authorities must have legitimate authority, they at least claim to have authority. Joseph Raz, Authority, Law and Morality, in Ethics in the Public Domain: Essays in the Morality of LaW and Politics $194-$ 221 (Joseph Raz ed., 1994).

${ }^{77}$ Depending on how broadly one defines authorities, there are two kinds of subjects from whom authorities seek cooperation: Private actors and officials. But for the purposes of our discussion we focus on authorities seeking cooperation from private actors. 
accordance with the law. This explains how legal competence or legal authority can become a vehicle of both governmental power and legal protection. Legal competence can be invoked by authorities to govern beyond their own physical control. By the same token, the lack of legal competence can constitute an effective legal challenge by subjects against authorities. The advantage of legal competence for subjects is that it operates not only ex-post factum but also ex-ante. Authorities will often have an interest in refraining from acting outside their legal competence motu proprio. Obviously, from the individual's perspective, ex-ante protection is preferred over ex-post protection because it prevents or stops the unlawful exercise of powers.

\section{Operational Powers May Overpower or Elude the Law}

The basic communicative scheme of invoking the law to obtain cooperation from subjects may become obsolete when authorities acquire operational powers of a certain size and quality. The operational powers may allow the authorities to execute the tasks themselves, to coerce subjects into compliance, or simply to make non-compliance physically impossible. Operational powers enable authorities to overpower or elude legal constraints that can otherwise protect individuals, such as legal competence.

In concrete situations, authorities may have sufficient operational powers to the effect that they can effectively act even when subjects do not cooperate or even when subjects may try to obstruct the authorities. Practically speaking, under these circumstances, the authorities can govern without the need to invoke the law. The law's enabling function becomes superfluous from a practical perspective. And if the law does not enable authorities, it is also less likely to constrain them. The basic mechanism of law that both enables and constrains authorities is put out of order, at least temporarily. Unlawful actions by authorities, especially physical acts, often fit in this scenario. Textbook examples are cases of police brutality. Typically, they occur in situations where police officers outnumber targeted individuals, and there are no, or only a few, bystanders present or the bystanders are not sufficiently organized. Targeted individuals may protest against the police actions' unlawfulness, but this will be to no avail, as under these circumstances, authorities tend to be unsusceptible to legal arguments. By contrast, when law enforcement agents are outnumbered by targeted individuals and bystanders, they are more inclined to conduct their operations by the book. Cases of police misconduct are spectacular examples where operational powers put ex-ante legal constraints out of order. But there are many other areas where authorities can afford to act unlawfully simply because they physically can. In the context of migration and border control, the push-back operations in the Mediterranean Sea are a case in point.

Sometimes operational powers overpower not only ex-ante legal constraints but also make exante legal protection pointless. Operational powers include both human resources, such as the corps of civil servants, and infrastructure. When used in specific ways, infrastructure enables authorities not so much to overpower ex-ante legal constraints, but rather to elude legal challenges altogether. A good illustration of operational powers as infrastructure eluding individual legal protection are border fences. Authorities can use coercive physical manpower to control the borders. But, they can also erect a border fence. When effective, the fence prevents individuals from crossing the border. The legal decision to erect the fence, the construction of the fence, and the fence's actual existence do not claim obedience from aliens seeking entrance to the territory. The aliens, in a way, do not matter. Moreover, from a technical legal perspective, it is difficult for aliens to identify the particular actions they may want to challenge legally ${ }^{78}$ because the erection and presence of

\footnotetext{
${ }^{78}$ Furthermore, whereas coercive powers almost automatically trigger legal awareness and caution, infrastructure is perceived as more benign. See Daintith, supra note 7 (contrasting imperium with dominium). To be sure, I am not saying that it is completely impossible to legally challenge the construction and maintenance of a border fence. It is however extremely difficult for an individual alien to do so. For more on the (il)legality of border walls, see Moria Paz, The Law of Walls, 28 EUR. J. INT'L L. 601 (2017).
} 
the fence do not constitute a legal act directed at these aliens. In the absence of an individual legal decision, it is extremely difficult, both practically and formally, for an alien to legally challenge the fence's presence under administrative law. The erection and presence of the fence can be qualified as a mere factual act. However, unlike factual acts, such as border guards coercing an individual alien or inflicting physical harm on an alien, the factual act of maintaining a border fence is not in and of itself coercive, thereby potentially triggering a cause of action such as a criminal or tortious liability, for example. ${ }^{79}$ Thus, whereas the physical and coercive capacity of the corps of civil servants enable authorities to overpower legal protection, operational powers as infrastructure allow authorities to simply evade individual legal protection.

\section{Operational Powers are Resilient}

Another reason why operational powers pose a challenge to individual legal protection is their autonomy and resilience. When they are sufficiently extensive, operational powers almost lead a life of their own. Operational powers rarely remain idle. They need an outlet and tend to be used. So, if large groups of human beings are mobilized, trained, and organized, it is likely that they will be put into action sooner or later. A case in point is the mobilization of troops and having a standing army. ${ }^{80}$ Not only human resources but also infrastructure and equipment rarely remain unused. Furthermore, operational powers have a particular resilience. Infrastructure initially built for a particular, temporary purpose often outlives its original function. A striking example of infrastructural resilience is the way Western European detention facilities built at the beginning of the twentieth century remained in place and in use throughout the remainder of the century by simply adapting their functions to the new "needs." Similarly, in most Western European states, it is not easy to make civil servants redundant on a large scale. The point here is to see the contrast with legal powers. When public authorities have their legal powers withdrawn, this can take immediate effect, even retroactively. This is because legal authority is a matter of normative convention. So, while the stroke of a pen can cancel legal competencies, operational powers take much more time to unwind. As a consequence, public authorities often have operational powers at their disposal that no longer correspond with the initial objective for which they were granted.

I have discussed three reasons why operational powers by themselves pose a serious risk of compromising legal protection. To be sure, I am not suggesting that operational powers always overpower and elude individual legal protection. But I am arguing that today, this risk is insufficiently mitigated because public law only has legal mechanisms that constrain the exercise of operational powers. We should also explore the possibility of having legal standards that constrain the build-up of operational powers.

\footnotetext{
${ }^{79} \mathrm{By}$ contrast from the perspective of moral philosophy, it has been argued that border control mechanisms such as fences are coercive. See Tendayi Bloom \& Verena Risse, Examining Hidden Coercion at State Borders: Why Carrier Sanctions Cannot be Justified, 7 Ethics \& Glob. Pol. 65 (2014); Arash Abizadeh, Democratic Theory and Border Coercion: No Right to Unilaterally Control Your Own Borders, 36 POL. THEORY 37 (2008).

${ }^{80}$ Contrary to civilian personnel, the withdrawal or demobilization of troops has always been understood as a clear problem of factual power. The historical examples are innumerable. In this respect, De Hoop-Scheffer, then the Dutch Minister of Foreign Affairs and later on the NATO Secretary General, was either completely naïve or simply acting in bad faith when saying that he was still hoping for a diplomatic solution on March 17, 2003 with more than 200,000 US troops battle ready at the Iraq border . See Floris van Straaten, Nederland wil V-raas,,niet voor de voeten lopen, NRC (Mar. 17, 2003), https://www.nrc.nl/nieuws/2003/ 03/17/nederland-wil-v-raad-niet-voor-de-voeten-lopen-7630829-a497369. The "outlaws" after the American Civil War and the Freikorper after WWI are just two of the many well-known examples reflecting the difficulties involved in de-mobilizing troops. On a more anecdotal note: "Cicero [when governor] after raising a considerable force to meet the threat of the Parthian army in Syria, had to do something with it, and so chose to attack the people of Pindenissus ...." So Cicero sent his forces on an expedition to a people relatively harmless to Rome, just to keep the troops busy and probably ensure them the spoils of war that were promised to them. Andrew Lintott, Imperium Romanum: Politics And Administration 53 (1993).
} 


\section{E. Public Law and the Build-Up of Operational Powers}

Throughout this Article, I have argued that the EU is entering a critical phase because, for the first time in its history, it will acquire significant and genuine operational powers. Operational powers allow authorities to overpower or elude standard legal mechanisms offering protection to individuals. Therefore, public law should not only place constraints on the exercise of operational powers, but there should also be legal standards constraining the build-up of operational powers. Today, public law lacks such legal standards. However, there are precursors in public lawinternational law, European law, constitutional law, and administrative law ${ }^{81}$-and Western legal thought that hint at the special nature of operational powers and their associated risks. In this Section, we will briefly discuss the most salient precursors and draw from them legal mechanisms that could be used to constrain the build-up of the EBCG's operational powers.

\section{Western Legal Thought and the Build-Up of Operational Powers}

Legal experts commenting on the EBCG do not raise the issue of operational powers as an inherent risk to individual legal protection. They certainly do not propose to put legal constraints on the buildup of the EBCG's operational powers. This legal blind spot should not come as a surprise. It was only from the second half of the nineteenth century that authorities were acquiring substantive operational powers. In effect, as Oakeshott has put it, "now, even the least powerful government enjoys a mastery quite unknown to the most powerful in earlier times." ${ }^{82}$ So probably, until the end of the ancien régime, the potentia of centralized authorities was simply not significant enough to become a core concern for legal and political writers. ${ }^{83}$ Accordingly, from early modernity onwards, the central question of political and legal thought in the West has been about the legitimacy and legal status of the power to make new law as opposed to upholding the existing law of the land - be it by a King, parliament, the people, constituting powers, ordinary courts, or constitutional courts. ${ }^{84}$

When the administrative state was rising by the end of the nineteenth century, scholars from Weber to conservative liberals noticed the expanding operational powers-especially the large corps of permanent, loyal, and trained civil servants. However, the central question of Western legal and political thought remained exclusively focused on the nation state's legal powers and the administrative state. ${ }^{85}$ So when legal theorists continued to develop a concept of the rule of

\footnotetext{
${ }^{81}$ For length purposes, I will not discuss precursors from domestic constitutional and administrative law.

${ }^{82}$ See Oakeshott, supra note 3 , at 371.

${ }^{83}$ Central authorities simply lacked the comprehensive corps of permanent, trained, equipped, salaried, and loyal civil servants comparable to our modern administrative state. See JUliUs RUfF, VIOLENCE IN EARLY MODERN EUROPE 1500-1800 (William Beik \& T.C.W. Blanning eds., 2001). The absence of a comprehensive and effective corps of officials was still the case in the context of the 18th century rise of "police" or "Policey." See Ernest Barker, The Development of Public Services in Western Europe 1660-1930 (1944); see also Pietro Costa, The Rule of Law: A Historical Introduction, in The Rule of Law: History, Theory and Criticism 77 (Pietro Costa \& Danilo Zanilo eds., 2007).

${ }^{84}$ See Simone Goyard-Fabre, Jean Bodin et le droit de la République (1989); Harold Berman, LaW and Revolution: The Formation of the Western legal Tradition (1983); see Mireille Hildebandt, Straf(Begrip) EN PROCESBEGINSEL: EEN ONDERZOEK NAAR DE BETEKENIS VAN STRAF EN STRAFBEGRIP EN DE WAARDE VAN HET PROCESBEGINSEL NAAR AANLEIDING VAN DE CONSENSUELE AFDOENING VAN STRAFZAKEN 257, 266-71 (2002).

${ }^{85}$ This focus on the normative quality of measures taken by the executive and the administration seems to fit a general preoccupation among especially German-speaking scholars with the dogmatic or doctrinal distinction between the judiciary (Justiz) and the administration ('Verwaltung'). Cf. Adolf Merkl, Zum Problem der Rechtskraft in Justiz und Verwaltung,

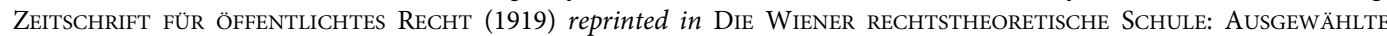
Schriften von Hans Kelsen, Adolf Julius Merkl und Alfred Verdross 1203-14 (H. Klecarsky, R. Marcić \& H. Schambeck eds., 1968). For a critical overview of the standard views on the distinction between administrative and judicial power, see Hans Kelsen, Justiz und Verwaltung, ZeITSCHRIFT FÜR SOZIALES RECHT (1919) reprinted in H. Klecarsky, R.Marcić and H. Schambeck (eds.) Die Wiener rechtstheoretische Schule. Ausgewählte Schriften von Hans Kelsen, Adolf JUlius MERKL UND ALFRED Verdross, 1203-1214 (1968).But even scholars trying to think through the administrative state from a more sociological and concrete order perspective beyond standard doctrinal paradigms were still exclusively focused on the normative quality of the legal order and not on operational powers, for example Santi Romano and Maurice Hauriou. For
} 
law as Rechtsstaat or état de droit in direct response to the emergence of administrative law from the second half of the nineteenth century, they focused entirely on the normative status of legal acts issued by the State, especially administrative authorities. ${ }^{86}$ They were trying to solve the puzzle of the origins, justification, hierarchy, and judicial review of a state that is the source of its own law. They did not spend much intellectual energy on another quintessential feature of the modern administrative state, namely its operational powers. Later on, liberal critics of the administrative state pointed to the dangers of the administration's legal power to change the law at will, thereby compromising the rule of law, especially legal certainty. ${ }^{87}$ They did not identify operational powers as posing a risk to the rule of law regarding individual legal protection.

A few scholars obliquely highlighted the relevance of distinguishing between the administration acting through law and the administration acting through physical acts. Some explicitly argued that the administrative state's true character is its capacity to intervene directly in social-economic life. Carl Schmitt acknowledged that when the administration acts through factual or physical measures (unmittelbare Aktion, vi armata, bloss faktische Vorgehen, or rein tatsächliche Massnahmen) such measures are not susceptible to legal invalidation but create a fait accompli (vollendete Tatsachen schaffen). Accordingly, the shooting of people cannot be "ausser Kraft gesetzt werden." 88

Hans Kelsen argued that what makes the administrative state truly administrative is the exercise of direct administrative power (unmittelbare Verwaltung). In other words, when the state intervenes (eingreift) physically and directly in social life. ${ }^{89}$ According to Ernst Forsthoff, the new administrative state increasingly and actively provides for its subjects through public services and welfare (Daseinsvorsorgen), ${ }^{90}$ calling for a rejection of the standard liberal constitutional and administrative law way of thinking. The liberal scheme of allegedly politically neutral law that arbitrates individual rights and freedoms and state powers has mainly become obsolete. ${ }^{91}$ The law should not so much protect the rights and freedoms of autonomous individuals, but should instead guarantee fair and just participation in public services. ${ }^{92}$ Furthermore, the administrative state cannot be politically neutral because it is directly involved in the highly political business of distributing basic goods and social-economic risks. ${ }^{93}$ The structure of Forsthoff s argument has some commonalities with my point about how operational powers may enable authorities to

the central tenets and a comparison of these two administrative law theorists, see Martin Loughlin, Santi Romano and the Institutional Theory of Law, in THE LEGAL ORDER xi-xxix (1917) (Mariono Croce ed.\& transl., 2017).

${ }^{86}$ See Costa, supra note 83 , at 93-102, 109-16.

${ }^{87}$ See e.g. Freidrich HaYeK, Road to Serfdom (1994). For a recent discussion of Hayek's critique, see David Dyzenhaus, Dreaming the Rule of Law in Law, in Liberty and State: OAKeshott, HayeK and SchmitT on the Rule of LaW 254 (David Dyzenhaus \& Thomas Poole eds., 2015). Also, Fuller looks exclusively at the normative quality and nature of managerial directives associated with the administrative state. According to Fuller, managerial directives with their focus on expediency and improving future behaviour lack the normative quality to satisfy the requirements of the rule of law. See Lon Fuller, $A$ Reply to Critics, in The Morality of LaW 207-13 (1969). Similarly, critics of the emergence of a 'droit social' in France pointed out how 'droit social' undermined the autonomy of individual free will in contract law. For a discussion of this cri-

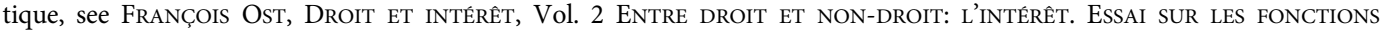
DU'EXERCE LA NOTION D'INTÉRÊT EN DROIT PRIVÉ 160-69 (1990).

${ }^{88}$ Carl Schmitt, Die Diktatur des Reichspräsidenten Nach Art. 48 der Weimarer Verfassung, in VERÖFFENTLICHUNGEN DER Vereinigung Deutscher StaAtsrechtslehrer (1924), reprinted in Carl Schmitt, Die DikTatur: Von DEN ANFängen DES MODERNEN SOUVERÄNITÄTSGEDANKEN BIS ZUM PROLETARISCHEN KLASSENKAMPF 246 (1994); CARL SCHMITT, LEGALITÄT UND LEGITIMITÄT 67 (2012).

${ }^{89}$ See Kelsen, supra note 85, at 1806-08, 1810-11.

${ }^{90}$ Ernst Forsthoff, Die Verwaltung als Leistungsträger (1938), reprinted in ERnST Forsthoff, ReCHTSFragEN DIE leistende Verwaltung, Res Publica. Beiträge zum offentlichen Recht 28 (1959) (“Aber die Vorsorge dafür, dass überhaupt gelebt werden kann, lag nicht annähernd in gleichen Umfang bei ihm [the State], wie heute. Insofern ist die Abhängigkeit des Menschen vom Staat in 19. und 20. Jahrhundert viel intensiver geworden, als sie es je in den vergangenen Jahrhunderten gewesen ist.") (emphasis added).

${ }^{91} I d$. at $22-24,35$.

${ }^{92} \mathrm{Id}$. at 42 .

${ }^{93} I d$. at $32-34,36$. 
simply elude the law. Yet, my point expresses a normative concern about how non-coercive operational powers easily escape the standard legal constraints such as fundamental rights. By contrast, Forsthoff, at that time a member of the Nazi party, welcomed the inadequacy of the liberal democratic state governed by the rule of law as he saw in it a justification for the emergence of the totalitarian state. $^{94}$

Much later, Niklas Luhmann pointed to the problematic legal status of infrastructure when denying "the design of the aisles in supermarkets or a computerized air traffic system . . . to be part of the legal order." ${ }^{25}$ Michel Foucault describes the exact conditions that enable the advent of a state with comprehensive operational powers when he analyzes the emergence of the various modes and rationalities of governance from the sixteenth and seventeenth century onwardswhich include police, discipline, security, and bio-politics. Yet, he is still very much focused on the genealogy of these rationalities. He does not identify the state's capacity to physically intervene by concrete actions as a distinct novelty of the modern administrative state. Furthermore, his inquiry is not informed by a concern for how to legally constrain the exercise of operational powers. ${ }^{96}$ Though Foucault himself did not undertake a complete examination of law, legal theorists have elaborated on his views about the law and applied his research methods to the law. ${ }^{97}$ However, these Foucauldian approaches to the law have not led to investigations into the relationship between operational powers and individual legal protection. Similarly, when legal scholars apply Foucault to EU migration law and border policies, they do not identify operational powers as distinctively problematic for the legal protection of migrants. ${ }^{98}$

Martin Loughlin is one of the few well-known contemporary public law scholars who explicitly uses Foucault in the context of operational powers as potentia. ${ }^{99}$ In his book on the foundations of public law, he spends an entire chapter on the concept of potentia, drawing mainly on Michael Oakeshott, Michel Foucault, and Michael Mann. ${ }^{100}$ According to Loughlin, potentia introduced a new mode of governance that poses a fundamental challenge to public law. The problem is the

\footnotetext{
${ }^{94}$ See Bernd Rüther, Überlebende und Überlebte Vergangenheiten: Zwei Starjuristen Einer Diktatur Unter sich. Anmerkungen Zu: Ernst Forsthoff - Carl Schmitt Briefwechsel 1926-1974, in 4 BERICHTE AUS DER WELT DES RECHTS: MYops 68-69 (2008).

${ }^{95}$ Niklaus Luhmann, Law as a Social System 154 (K. Ziegert trans., 2004).

${ }^{96}$ Michel Foucault, Sécurité, Territoire, Population, Cours Au Collège De France. 1977-1978, 109-11 (2004); Michel Foucault, Naissance de la biopolitique. Cours au Collège de France. 1978-1979 (2004).

${ }^{97}$ See e.g., Ben Golder \& Peter FitzPatrick, Foucault's Law (2009); Alan Hunt, Encounters with Juridical Assemblages: Reflections on Foucault, Law and the Juridical, in Re-REAding FouCAUlT: ON LAW, Power AND RigHTs 64-84 (Ben Golder ed., 2013).

${ }^{98}$ See Marie-Laure Basilien-Gainche, Leave and Let Die: The EU Banopticon Approach to Migrants at Sea, in 'BOAT Refugees’ and Migrants at Sea: A Comprehensive Approach. Integrating Maritime Security with Human Rights 327-52 (Moreno-Lax \& Papastavridis eds., 2016); see also Elspeth Guild, From Persecution to Management of Populations: Governmentality and the Common European Asylum System (Radbound Univ. Nijmegen, Working Paper No. 2012/04, 2012). Guild shows how the logic of managerialism and bio-politics hampers legal protection of migrants, but she does not look at operational powers.

${ }^{99}$ DeMuth also identifies the power to intervene directly as a characteristic of the contemporary administrative state. See Christopher DeMuth, Can the Administrative State be Tamed?, 8 J. LEGAL ANALYsis 121-90 (2016). But he focuses on the growing capacity of information and communication technology, which would correspond with Hood's "nodality." See id. at 157-62. He uses the advances of information and communication technology as a "materialist explanation for the ascendency of executive government" providing an account much superior to the standard intellectual explanation. See id. at 162. His objective is to explain " $\mathrm{t}]$ he most impressive characteristic of administrative law is evolutionary fitness, its seeming organic capacity for growth and adaptation.” Id. at 157. By contrast, the objective of the present article is to understand how operational powers constitute an obstacle for legal protection and to argue in favor of placing legal constraints on their build-up.

${ }^{100}$ Martin Loughlin, Foundations of Public Law 164-71, 407-34 (2010) (detailing his discussion of potentia). Some read into Loughlin's account of 'potentia' not so much operational powers as in physical capacity but rather a special form of lawmaking power that is in a way self-generating, for example, eluding standard public law constraints. See Denis Baranger, Uncovering the Foundations of Administrative Law, in QUESTIONING THE FoUNDATIONS OF PUBLIC LAW 250-51 (Michael A. Wilkinson \& Michael W. Dowdle eds., 2018). I believe that potentia indeed carries the risk of being self-generating, thereby eluding normal public law constraints, but that its essence is the power to intervene in physical reality.
} 
underlying logic potentia, namely the ultimate aim of a political and legal order caring for the population and providing the necessary infrastructure. This leads to potentially unlimited state power in three ways. First, because the government's task is the care of the population, there is simply not an area of social life where the government and the law cannot intervene. In other words, there are no intrinsic limitations on the power of government and law (ratione materiae). According to Loughlin, jurisdictional limitations on what the government may do become obsolete. ${ }^{101}$ Second, because the government is responsible for structuring social interactions and actual output, effectiveness, and results, there is in principle no intrinsic limitation as to the means of government. Third, care for the population means that the law is no longer about deciding and addressing conflicts between people with different interests, resources, and beliefs; the law no longer aims to mediate between different claims about truth, reality, and what is to be done. It adopts a managerial perspective of a common, homogeneous interest and an overall win-win situation. It ceases to be "a de jure fragmented public space assuring unresolvable confrontation." ${ }^{102}$ Instead, these underlying conflicts are silenced in the name of a new higher universal truth. ${ }^{103}$

Loughlin focuses primarily on the logic of potentia, whereas I focus on the physical aspect of operational powers as potentia and legal protection. Still, I share his ultimate concern. Loughlin warns against how the hegemonic, expansive, and over-inclusive logic of potentia turns every measure of public policy into a question of absolute and social truth: What best serves the higher goal of satisfying social needs? This logic dissolves political, social, and legal conflicts into a question of truth. As if there are no conflicting and opposing interests, but just a false understanding of the truth. This logic will render obsolete the very fabric of law and public law, namely legal distinctions and categories that openly recognize that the interests, functions, and powers of the various actors and institutions are not fully aligned, but are continuously in conflict. ${ }^{104}$ The logic of potentia puts the law out of order.

The point of this brief excursion in legal thought is twofold. First, it explains why today, legal experts and scholars have not paid attention to the build-up of operational powers from the perspective of legal protection. It seems primarily a matter of legacy. We did not find arguments in legal theory and jurisprudence to the effect that legal thinkers should not or need not address the risk of operational powers compromising individual legal protection. Second, when legal scholars sporadically touch on the issue of the state's factual power, either obliquely or directly, their observations actually support the claim about the insufficiency of legal mechanisms that only constrain the exercise of operational powers, but not their build-up.

\section{International and European Law and the Build-Up of Operational Powers}

There are only a few examples of positive law coming close to constraining the build-up of operational powers. These precursors point to an awareness of the risks associated with operational powers. In public international law, a clear case in point is the Non-Proliferation Treaty. ${ }^{105}$ We might even say that a large part of classical international law was all about controlling the build-up of operational powers and organizing counter forces, namely the capacity to wage war. One of the central instruments of classic international law until World War I was peace treaties. ${ }^{106}$ They constituted the basis for the so-called jus publicum Europeanum. ${ }^{107}$ One of the

\footnotetext{
${ }^{101} I d$. at 462 .

${ }^{102}$ See LoUghlin, supra note 100, at 465 (citing Gauchet).

${ }^{103}$ See id.

${ }^{104}$ See id. at 463 (citing Vibert noting the mixing up of previously separated powers at the supranational and transnational level).

${ }^{105}$ Treaty on the Non-proliferation of Nuclear Weapons, Jan. 7, 1968, 21 U.S.T. 483, 729 U.N.T.S. 161.

${ }^{106} \mathrm{Cf}$. Randall Lesaffer, Peace Treaties and International Law from Lodi to Versailles (1454-1902), in PEACE TREATIES AND International law in European History. From the Late Middle Ages to World War One 9-44 (Randall Lesaffer ed., 2004).

${ }^{107}$ See Carl Schmitt, Der Nomos der Erde im VölKerrecht des Jus Publicum Europaeum (1950).
} 
primary purposes of this jus publicum Europeanum was to limit destructive and unproductive wars on the European continent. In an almost similar vein, the predecessor of the current European Union, the European Coal and Steel Community ("ECSC"), also sought to control the capacity to wage war. ${ }^{108}$ In fact, it would not be a stretch of the imagination to construe the Treaty on the ECSC as the last major peace treaty of the European continent. The ECSC was all about constraining the physical power to wage war by controlling production and production capacity of modern war machinery's basic components, namely, coal and steel. In this respect, the rationale behind classic international law could operate as a cue for thinking about putting legal constraints on the build-up of operational powers.

I presented the ECSC as an example of legal constraints on the build-up of operational powers. Strictly speaking, it is not about the operational powers of public authorities. It is about the production and the capacity to produce coal and steel tout court. For example, under the ECSC, capacity and production restrictions were imposed on coal and steel enterprises instead of public authorities. ${ }^{109} \mathrm{By}$ contrast, a genuine and rare example of European law placing legal constraints on building up or maintaining operational powers can be found in the Schengen regime. A core provision of the Schengen Border Code ("SBC") prohibits conducting border checks at the Schengen area's internal borders. ${ }^{110}$ To make it more difficult to reintroduce border checks in violation of Article $22 \mathrm{SBC}$, the Border Code provides for the dismantling of the border control infrastructure. ${ }^{111}$ In other words, the SBC explicitly targets the infrastructure of the Member States needed for conducting internal border checks. The provision directly constrains the build-up and maintenance of operational powers.

Another example of EU law intervening directly in the build-up of operational powers is the General Data Protection Regulation. It introduced the mechanism of "data protection by design." 112 This means that those responsible for processing personal data must build into their Information and Communications Technology ("ICT") systems safeguards for privacy and fundamental rights. In other words, the IT systems must be technically designed to prevent data protection violations. The protection by design is mostly a countermeasure disabling certain functionalities of the IT system. For example, the Regulation leaves open the technical possibility to manually reactivate its functionality. The data protection law is not targeted at the operational powers of public authorities per se, but rather at anyone processing personal data, including the authorities of the Member States and the EU. Moreover, in terms of Hood, it is strictly speaking not a matter of the organization or operational powers, but instead a matter of nodality. Still, it is a clear example of how law constrains the capacity to do wrong.

Even more than data protection law, the logic of EU competition and environmental law is all about constraining the capacity to act unlawfully. To be sure, competition and environmental law are not aimed at constraining public authorities' operational powers. Still, these legal fields show how public law tries to constrain the physical capacity to act unlawfully. In competition law, companies are required to obtain ex-ante clearance or approval to undertake a merger or acquisition to prevent them from gaining a dominant market position. In such cases, there is no actual anticompetitive behavior or the abuse of a dominant position by the company in question. The whole point of these types of regulations is to prevent the company from becoming so powerful that it becomes too easy to display anti-competitive behavior and make abuse of its dominant position. Similarly, many norms of environmental law prohibit certain activities as well as the possession of

\footnotetext{
${ }^{108}$ Treaty Establishing the European Coal and Steel Community, Apr. 18, 1951, 261 U.N.T.S. 140 [hereinafter ECSC].

${ }^{109}$ See e.g., id. at arts. 2, 4, 58 .

${ }^{110}$ Regulation 2016/399 of Mar. 9, 2016, on a Union Code on the Rules Governing the Movement of Persons Across Borders (codification), 2016 O.J. (L 77) 23, art. 22 (EU) [hereinafter Schengen Borders Code].

${ }^{111} I d$. at art. 24.

${ }^{112}$ Regulation (EU) 2016/679, at art. 25, of the European Parliament and of the Council of April 27, 2016, on the Protection of Natural Persons with Regard to the Processing of Personal Data and the Free Movement of Such Data, and Repealing Directive 95/46, 2016 O.J. (L119) 1 (EC). For this mechanism see N. van Dijk, A. Tanas, K. Rommetveit \& C. Raab, Right Engineering? The Redesign of Privacy and Personal Data Protection, 32 InT'L Rev. L., Computers \& TECH. 230 (2018).
} 
certain installations and hazardous materials. The underlying logic of such prohibitions is to prevent the build-up of the factual capacity from causing environmental damage. In other words, it is an explicit acknowledgment that normal legal rules prescribing prudent behavior and attributing tortious and criminal liability are not sufficient constraints on operational powers-sometimes public law must impose ex-ante constraints on the build-up of factual capacity. This is also reflected in the precautionary principle, a typical construction of environmental law. ${ }^{113}$ Accordingly, certain new technologies may not be used or will require precautionary measures because there is too much scientific uncertainty about their possible adverse environmental effects.

I do not think that we should transpose the precautionary principle from environmental law and apply it to the build-up of operational powers. The precautionary principle of environmental law is in a way too sophisticated as it aims to address scientific uncertainty. Also, the reversal of the burden of proof it entails is not necessary in the context of operational powers. The problem with operational powers is not so much scientific uncertainty about its effects on legal protection. The challenge is, rather, to simply acknowledge that operational powers pose a risk, certain or uncertain, to legal protection and that those risks may not be sufficiently mitigated through the normal mechanisms of legal protection. Therefore, what can be borrowed from the precautionary principle in the context of operational powers is its ex-ante focus on risk assessment and precautionary measures. ${ }^{114}$

\section{Legal Constraints on the Build-Up of the EBCG's Operational Powers}

From the existing legal arrangements dealing with operational powers, we may draw analogies for the concrete case of the EBCG. Roughly speaking, there are two types of possible constraints on the build-up of operational powers: Actual constraints limiting the extent and nature of operational powers and the creation of mitigating counterforces. The latter is, strictly speaking, not a constraint on the build-up of operational powers. But to the extent that the operational counterforces are put in place coevally with the creation of operational powers, we may consider them to be physical constraints on the build-up of operational powers. The operational counterforces' function is either to deter the unlawful use of operational powers or to mitigate its effect. The counterforces are necessary in contexts where limiting the build-up of operational powers is undesirable or impossible. For instance, effective policing operations require a certain amount and quality of operational powers that are necessarily coercive and intrusive for individuals. By their very nature, coercive and intrusive actions that are otherwise lawful always run a relatively great risk of degenerating into the unlawful use of force. This risk is inherently and inevitably associated with any level of effective coercive and intrusive powers. Accordingly, limiting the build-up of operational powers is not a feasible solution to ensure effective individual protection. In these contexts, physical counterforces may deter the unlawful use of otherwise indispensable coercive and intrusive powers.

As mentioned earlier, in theory, the logic of the precautionary principle would be a fitting legal constraint on the build-up of the EBCG's operational powers. It should involve a thorough mapping of the significant and most likely risks to effective legal protection. This is lacking in the current new Regulation. In the paragraph on fundamental rights, the new Regulation asserts that the border guards will respect fundamental rights. This statement expresses a commitment to

\footnotetext{
${ }^{113}$ For a recent application of the precautionary principle with references to the leading case law and legal literature, see R. Kegge \& A. Drahmann, The Programmatic Approach: Finding the Right Balance Between the Precautionary Principle and the Right to Conduct a Business, 17 J. FOR EUR. ENVTL. \& Plan. L. 76 (2020).

${ }^{114}$ The version of the precautionary principle that comes closest to what I have in mind is the idea of precautionary measures laid down in the U.S. Constitution to mitigate or prevent abuse of powers. The precautionary measures extend to the abuse of operational powers, most prominently the risk of abuse of a federal standing army. Yet, the discussions about precautionary principles in U.S. constitutional law do not identify operational powers as distinctively problematic. For a critical discussion of the precautionary principles in U.S. constitutional law, see A. Vermeule, Precautionary Principles in Constitutional Law, 4 J. Legal AnAlysis 181 (2012); see also A. Vermeule, Optimal Abuse of Power, 109 Nw. UnIV. L. REV. 673 (2015).
} 
respect fundamental rights, but it is not a risk assessment of possible fundamental rights violations caused by the EBCG when exercising its operational powers. ${ }^{115}$ The risk assessment requires input from people with hands-on expertise in border operations, including those at the receiving end of such operations. ${ }^{116}$ I am not such an expert. For now, I can only sketch some broad risk categories that seem particularly relevant for the EBCG from the perspective of an outsider.

The major risk posed by the EBCG's operational powers is the powers used for the policing aspects of the border control tasks. ${ }^{117}$ To what extent are the number of guards in the standing corps, the type of training and experience oriented towards civilian law enforcement versus military operations, and the equipment—such as the types of firearms — tailored to the policing tasks of the EBCG? What are the risks of an unlawful exercise of operational powers? What physical counterforces are put in place to reduce the risks and mitigate the unlawful use of operational powers? The answers to these questions involve a detailed assessment of the border operations' practical elements and concrete contexts. This assessment must be directly related to the various elements of the operational powers. The precautionary test must involve a typology and list of concrete forms of the unlawful exercise of operational powers. It is up to experts, and in the first place, the Commission, who proposed the build-up of operational powers for the EBCG, to come up with a concrete, detailed list of risks.

The precautionary principle should involve assessing the risks associated with the border guards and their personal equipment and the risks associated with other assets and infrastructure. For example, a frequent source of fundamental rights violations in the EU border management is the reception conditions of migrants. The common critique and response are to improve the reception conditions and training of reception personnel. ${ }^{118}$ The question is whether such responses will ever be adequate. Often, the actual reception centers are located in sites originally built as detention facilities or military camps. This means that the very architectural and physical make-up of the actual reception centers may be structurally unsuitable for hosting migrants, especially families and minors, irrespective of well-intended efforts to improve reception conditions. Furthermore, authorities tend to use their infrastructure, even when the infrastructure is not suitable for the task at hand. This is especially the case when there are no immediate alternatives available. In other words, by simply having certain operational powers at its disposal, in our example reception centers, the EBCG runs a structural risk of violating reception conditions. ${ }^{119}$ Under a precautionary test, the Commission will have to explain that the risk of fundamental rights violations is proportionate to the benefits of the EBCG having the centers at its disposal.

Another risk associated with infrastructure is that infrastructure allocated for one purpose may be used for another. Though efficient from the perspective of asset utilization, it may create disproportionate operational powers. Such misappropriation becomes increasingly likely when authorities have to perform tasks with conflicting priorities. The EBCG runs this risk as it is supposed to combine its primary task of policing the borders with additional search and rescue ("SAR") operations. In fact, critical international and EU law experts actually want the EBCG to make search and rescue operations a higher priority and shore up its SAR capabilities. ${ }^{120}$

\footnotetext{
${ }^{115}$ See supra note 13.

${ }^{116}$ The closest Annex V of the new Regulation comes to identifying the risks of abuse is the small paragraph on the use of drugs by border guards. There is no assessment of risks associated with the operational powers themselves in connection with frequently occurring scenarios.

${ }^{117}$ For reports of coercive actions taken during Frontex operations including shooting at migrants in Progress Law Network, supra note 66.

${ }^{118}$ Rijpma, supra note 62 at $19-20$.

${ }^{119}$ To be sure, the reception centers are not part of the EBCG infrastructure. Yet, EBCG border guards are deployed in the centers.

${ }^{120}$ See Rijpma, supra note 62 , at 25 . Even if the EU has a legal duty to proactively organize and maintain SAR services, my point is not that the EU should not take up this task. Rather, I would argue that this task should not lie with the same EU agency that is also in charge of border controls. For the technical legal question of whether the EU has a duty to render
} 
Though well-intended, a stronger role for the ECBG in SAR may turn out to be counterproductive. First, in off-time, the SAR capabilities may be used for purposes other than SAR, such as policing operations. Second, suppose during the same operation the EBCG must conduct both policing tasks and SAR interventions. In that case, it may neglect the latter and even use the SAR capabilities for the policing tasks. A genuine precautionary test must also weigh the risk of the improper use of infrastructure.

Apart from introducing a precautionary test comprising a risk assessment of coercive powers and infrastructure, we must also consider introducing operational counterforces. Because coercive and intrusive operational powers are indispensable for the EBCG, limiting only its operational powers is undesirable. Therefore, operational counterforces must be put in place. At first glance, the Fundamental Rights Officer seems like a good example of a counterforce. However, under the previous Regulation as well as the new Regulation, the FRO does not constitute a genuine operational counterforce. A serious operational counterforce is a truly independent and operational fundamental rights unit. Independent means that the officials are not part of the EBCG but are from another EU agency. Operational means that at least two officials are physically present at the site of concrete border operations. The officials should not only monitor the exercise of operational powers in situ and in real time, but also should have the legal and physical capacity to intervene. This goes further than what legal experts have been proposing. They see the monitoring function as looking "regularly at the conditions" under which Frontex operations take place. ${ }^{121}$ The protective ex-ante effects of such a monitoring mechanism depend on deterrence and the improvement of operational procedures. But they do not offer a real physical counterforce at the actual moment when operations go wrong. I submit that a genuine counterforce against the EBCG's operational powers entails a fundamental rights unit with an ongoing physical presence at every border operation with powers to intervene on the spot.

\section{F. Conclusions}

When the new Regulation is fully implemented, the EU will acquire significant genuine operational powers for the first time in its history. This Article has argued that the conferral of operational powers on the EU, especially the EBCG, poses a serious risk to individual legal protection. This Article has identified three reasons why operational powers may compromise individual legal protection. First, the law can constrain the exercise of public powers insofar as authorities have an interest in governing through law. The law can constrain authorities to the extent that authorities need the law to ensure cooperation from subjects. As long as authorities need to govern by legal powers, they remain dependent on the perceived lawfulness of these legal powers' exercise. Legal norms are good at constraining the exercise of legal powers, but are less powerful against the exercise of operational powers. Second, once authorities have operational powers of a certain extent and kind, they can afford to operate against and without the law. Operational powers enable authorities to overpower or even elude the legal mechanisms that normally constrain the exercise of public power. Third, operational powers are extremely resilient. While legal powers can be withdrawn and invalidated with the stroke of a pen, even retroactively, the physical existence of operational powers cannot be undone by a legal act. This is why this Article urges jurists to explore legal mechanisms that place substantive size and quality constraints on the conferral of operational powers in the EU.

So far, jurists have remained virtually silent as to how the build-up of operational powers may compromise individual legal protection. For example, experts in EU migration law have raised legitimate concerns about how the EBCG may exercise its operational powers. But when it comes

assistance and the scope of such a duty, e.g., the EU is not a party to the SAR Convention and not a flag state under the UNCLOS, Trevisanut, supra note 21 , at 130-32.

${ }^{121}$ CARRERA ET AL., supra note 23 , at 58 . 
to proposing legal mechanisms ensuring the protection of individuals, they focus exclusively on constraining the exercise of operational powers, not on the build-up of operational powers. This Article explained that this blind spot is a legacy from Western legal thought that has been preoccupied almost exclusively with questions about the normative status of the legal power to make new law. This exclusive focus on legal powers persists even into our era, where states have massive operational powers at their disposal. Still, it also followed from our discussion that there is nothing within Western legal thought that opposes putting the build-up of operational powers on the agenda of jurists. In effect, some influential legal scholars have obliquely and occasionally pointed to the special nature of operational powers. Furthermore, this Article found legal arrangements from international and European law that function as precursors of what may become possible legal constraints on the build-up of the EBCG's operational powers. The most promising legal constraint is the precautionary principle. In the context of the EBCG, the precautionary principle should involve a detailed mapping exercise of the potential rights violations during border operations. Furthermore, taking the build-up of operational powers seriously also means introducing operational countermeasures to mitigate operational powers. One possible operational countermeasure against the EBCG's operational powers could involve creating fundamental rights units that are physically present during border operations with the power to physically intervene and not just monitor operational conditions.

Clearly, at the national level of the Member States, it would be politically unfeasible and democratically undesirable to place legal constraints on the build-up of operational powers. By contrast, we may expect resistance against the conferral of operational powers on the EU when the media and politicians critical of the EU pick up on the issue. Precisely the introduction of legal constraints may make the build-up of EU operational powers more politically and democratically acceptable.

Finally, it should be clear that legal constraints on the build-up of operational powers do not equal the barring of operational powers. This Article does not argue against the conferral of operational powers on the EU. More generally speaking, this Article is not an argument against the administrative state or the welfare state. Neither does this Article claim that the exercise of operational powers necessarily has a more adverse impact on individuals than the exercise of legal powers. This Article merely urges experts in EU law not only to look at ways to legally constrain the exercise of public powers, but also to explore substantive legal norms governing the build-up of operational powers.

Bas Schotel Assistant professor Faculty of Law, University of Amsterdam.

Cite this article: Schotel B (2021). EU Operational Powers and Legal Protection: A Legal Theory Perspective on the Operational Powers of the European Border and Coast Guard. German Law Journal 22, 625-649. https://doi.org/10.1017/ glj.2021.29 